\title{
SUMMARY OF THE ANCESTRAL ROCKY MOUNTAINS EPEIROGENY IN WYOMING AND ADJACENT AREAS
}

by Edwin K. Maughan ${ }^{1}$

U.S. Geological Survey Open-File Report OF 90-447

This report is preliminary and has not been edited nor reviewed for conformity with U.S. Geological Survey standards and nomenclature.

\footnotetext{
${ }^{1}$ U.S. Geological Survey, Denver, Colorado 80225
} 


\title{
Summary of the Ancestral Rocky Mountains Epeirogeny in Wyoming
}

\author{
and Adjacent Areas
}

\section{by}

\section{Edwin K. Maughan}

The Ancestral Rocky Mountains comprise a complex of northwesterlytrending uplifts (fig. 1) of late Paleozoic age in the central Rocky Mountains of Colorado and adjacent areas. These uplifts occur in approximately the same region as the Late Cretaceous-early Tertiary Laramide uplifts in the central Rocky Mountains, but were oriented differently. The Ancestral Rockies formed along an epeirogenic belt that reached northwestward into the region from the Ouachita area in Oklahoma. The principal highlands of the Ancestral Rockies, the Uncompahgre uplift and the Ancestral Frontrange, lay mostly in Colorado, but the latter highland extended into south-central Wyoming on the site of the present-day Sierra Madre. Also in Wyoming, the Pathfinder uplift lay en echelon northeast of the Frontrange highland in the vicinity of the northern Laramie Mountains, but was a minor lowland by comparison. Another lowland in the vicinity of the Black Hills of even less relief paralleled the same en echelon trend. The en echelon belt of uplifts extending from the Uncompahgre on the southwest to the Black Hills seems to have been composed of northwest-trending spurs on the northwest flank of the northeast-trending Transcontinental arch.

Similar north-northwest-oriented lowlands developed in northwestern Wyoming and adjacent areas, but Late Mississippian and Early Pennsylvanian structural trends in south central Montana were west-northwest. The Beartooth platform, a more or less east-west-trending lowland in Montana adjacent to the northern Wyoming border and Yellowstone Park, lay to the south of the Big Snowy trough and the west-northwest orientation of these features suggests that there were differently directed epeirogenic stresses in that area or that the development of these features were directed along pre-existing west-northwest structures. The north-of-west trend of the Big Snowy trough and the Beartooth platform seem to be related to a probable aulacogen in central Montana where tectonism from the Ouachita orogenic belt had a different pattern, possibly with a strike-slip component of movement.

The northwestern terminus of the Ancestral Rockies highlands, the Pathfinder uplift, and the lowland in the vicinity of the Black Hills was against the Sweetwater trough, which was an east-northeast-trending synclinorium coincident during late Paleozoic time with the Wyoming lineament of Ransome (Maughan and Perry, 1984) . However, uplifts northwest of the Sweetwater trough seem to continue the trends of the Ancestral Rocky Mountains into lowlands in northwestern Wyoming and southern and into southwestern Montana that may be extensions of these 
uplifts. The Bannock uplift, which is a late Paleozoic lowland that has been tectonically transported and telescoped eastward in the overthrust belt in western Wyoming, may be a northwesterly extension of the Uncompahgre highland. A lowland that is evident in the southern Gallatin Range in the Yellowstone Park area and to the northwest into immediately adjacent areas in Montana, seems to extend the trend of the Ancestral Frontrange to the northwest. The Darton ridge, in the vicinity of the northern Bighorn Mountains, seems to be a late Paleozoic lowland that extends the trend of the Pathfinder uplift to the northwest. The Miles City arch in southeasternmost Montana may be an extension of the Black Hills lowland, but it also may have affinity with the Beartooth platform. Each of these uplifts is evidenced by erosional unconformities, a lacuna in the rock record, and lithologic facies indicative of nearby terrigenous sources of the sediments.

The Ancestral Rocky Mountains developed in response to stresses during the late Paleozoic from the suturing of the North American plate in the Ouachita and Marathon regions (Kluth, 1986). There also seems to have been concurrent plate-to-plate collisions in the Appalachian orogenic belt along the eastern margin of North America. The rock record and structures in the Cordilleran region indicate that there was appreciable instability and diastrophism in that region during the late Paleozoic and current studies suggest that tectonic events there were approximately contemporaneous with late Paleozoic epeirogenic events evident in Wyoming and adjacent areas.

The Ancestral Rocky Mountains epeirogeny comprises three tectonic events. The first epeirogenic event took place during latest Mississippian to earliest Pennsylvanian time, about $325 \mathrm{Ma}$. The second event took place during Middle Pennsylvanian (late Atokan) time, about $315 \mathrm{Ma}^{1}$. The third, a weaker event, took place during Late Pennsylvanian to Early Permian time, about $285 \mathrm{Ma}$. Two precursor tectonic events, which occurred during Late Devonian and about middle Meramecian (early Late Mississippian) time, respectively about $360 \mathrm{Ma}$ and $330 \mathrm{Ma}$, seem to have foreshadowed the Ancestral Rocky Mountains epeirogeny. Two successive tectonic events, one about late Early Permian, about $250 \mathrm{Ma}$, and the other during Late Permian prior to Early Triassic deposition, between about 240 and $230 \mathrm{Ma}$, seem weakly to echo the major Ancestral Rocky Mountain epeirogeny in the Western Interior. These tectonic events and their times of occurrence are evidenced by the distribution, lithofacies, and preservation of Pennsylvanian and Lower Permian depositional sequences in the Western Interior of the North American cratonic shelf.

The first depositional sequence in the Pennsylvanian, which was initiated by the Mississippian-Pennsylvanian Ancestral Rocky Mountains epeirogeny, includes the Tyler Formation and the Alaska Bench Limestone of

1 Geologic time estimated from Geologic Time Table chart compiled by F.W.B. van Eysinga, 3d edition published 1975, by Elsevier Scientific Publishing Co., Amsterdam. 
the Amsden Group in Montana, the upper part of the Manning Canyon Formation and the Round Valley Limestone in Utah and parts of southwestern Wyoming, the Amsden Formation (restricted to exclude the Darwin Sandstone Member) in northwestern Wyoming, the lower member of the Casper, the Hartville, and the Minnelusa Formations in eastern Wyoming, and the lower member of the Fountain Formation in Colorado (figure 2). These Pennsylvanian sediments were deposited unconformably above Mississippian age rocks in most of the region, and upon Precambrian rocks in southeastern Wyoming and adjacent parts of Colorado and Nebraska.

The Early Pennsylvanian and possibly latest Mississippian sediments of the Tyler Formation in the Snowcrest-Big Snowy trough in Montana and the coeval Manning Canyon Formation in the Sweetwater trough indicate sequential overlap of valley-filling fluvial, deltaic, and marine deposits. During this early depositional stage, the Wyoming shelf was a lowland where the subaerially exposed Mississippian carbonate rocks were weathered and dissolved to form karst, regolithic breccias, and an accumulation of terra rosa soils. Alluviation in the valleys was succeeded by marine deposition of the Alaska Bench Limestone in Montana and the Round Valley Limestone in northern Utah and adjacent areas in southwestern Wyoming as the Pennsylvanian sea inundated these troughs. The sea then spread shallowly onto the adjacent lowland shelf in Wyoming and adjacent areas where coeval sedimentary rocks comprise the Amsden. Terra rosa paleosols, which had formed by weathering of the Mississippian carbonate rocks on the Wyoming shelf lowland, were eroded in the intertidal zone of the transgressing Early Pennsylvanian sea and redeposited in the redbeds of the Horseshoe Member of the Amsden (fig. 2). The intertidally deposited redbeds were succeeded by the more normal marine deposits of thin interbedded limestone and mudstone of the Ranchester Member of the Amsden as the sea subsequently deepened.

Contemporaneously with the Late Mississippian-Early Pennsylvanian diastrophism, Precambrian rock terrains were exposed and eroded in newly elevated terranes of the Ancestral Rocky Mountains. Arkose and arkosic sand from these uplands were deposited in the lower member of the Fountain Formation during Early to Middle Pennsylvanian time. The lower part of the Fountain comprises fluvial stream and fan-delta sediments deposited adjacent to the mountains on the coastal plains and intertidal mudflats as the rising Early Pennsylvanian sea engulfed the lowlands. Finegrained sediments of clay, silt, and fine sand derived from the mountains, and muds derived from the ravinement of the terra rosa on the lowlands were intertidally deposited across most of Wyoming as the redbeds of the Horseshoe Member of the Amsden Formation during late Morrowan time. Subsequent deepening of the epicontinental sea resulted in the depositional transition into the limestone of the Ranchester Member of the Amsden Formation during early Middle Pennsylvanian (Atokan) time. The Middle Pennsylvanian orogenic disturbance in middle to late Atokan time terminated Amsden deposition. 
The Ancestral Frontrange uplift was orogenically rejuvenated during Middle Pennsylvanian (probably late Atokan) time. The adjacent Wyoming shelf seems mostly to have remained shallowly submerged by the epicontinental sea during related Middle Pennsylvanian epeirogeny. The Amsden strata on the shelf were erosionally bevelled or they were entirely eroded in some areas because of differential uplift across the region. Middle Pennsylvanian diastrophism seems to have occurred far beyond the Wyoming province, and the uplift initiated the transport of quartzose sand from an unidentified northerly provenance that was deposited in the Quadrant and Tensleep Sandstone (Saperstone and Ethridge, 1984). Arkosic sand came more locally from Siouxia to the east and from rejuvenated mountainous terrains in the Ancestral Frontrange. The arkoses are incorporated in the upper member of the Fountain Formation in Colorado and tongues extend into the middle member of the Casper Formation in south central Wyoming and into the Morgan Formation in southwestern Wyoming and adjacent areas in northeastern Utah.

The Quadrant-Tensleep erg prograded across the Wyoming shelf from the north or northwest during Middle Pennsylvanian (Des Moinesian) and possibly through most of Upper Pennsylvanian (Missourian and Virgilian) time (Maughan, 1975, p. 287-288). Initial deposits of thin, interbedded sandy dolomite, sandy mudstone, and sandstone that comprise the Devils Pocket Formation in central Montana and the dolomitic member of the Tensleep Sandstone in Wyoming displaced the epicontinental sea on the Wyoming shelf and were succeeded by eolian dunes that comprise the upper member of the Tensleep in northwestern Wyoming. Tongues of these subaqueous and eolian deposited facies extend into the Morgan and Weber Formations, into the middle member of the Casper Formation in southern Wyoming, and into the middle members of the Hartville and the Minnelusa Formations in eastern Wyoming. Equivalent strata mostly of sandy limestone beds in the Wells Formation in western Wyoming were deposited in a chiefly marine environment.

The absence of the lower part of the Pennsylvanian, the Amsden sequence, beneath the upper part of the Pennsylvanian, the Tensleep sequence, is indicative of Early or Middle Pennsylvanian lowland uplifts of the ancestral Rocky Mountains at places in Wyoming. The Bannock uplift, the Beartooth platform, the Miles City arch, the Pathfinder uplift, and the ancestral Front Range uplift are large areas where the Amsden and equivalent strata of the lower sequence were partially eroded or are entirely missing. Numerous smaller areas of erosionally truncated or bevelled Amsden, including the Darton Ridge, provide evidence that the Middle Pennsylvanian epeirogeny contemporaneously produced a complex of smaller, uplifted blocks of terrain throughout Wyoming.

Normal faults coincident with north-northwest-trending lineaments (Maughan, 1983; Maughan and Perry, 1986) seem to bound the uplifts and to define a complex set of horsts and grabens that comprise the Ancestral Rocky Mountain system in Wyoming. This tectonic pattern indicates 
northeast-southwest extension in response to the compressional forces directed northwesterly into the central Rocky Mountains region from the Ouachita-Marathon orogeny (Kluth, 1986). Most of the uplifts are terminated along the conjugate set of lineaments that trend east-northeast. The principle of east-northeast trends is the Wyoming lineament of Ransome (1915, p. 294-295), which approximately marks the northwestern termini of the Uncompahgre, Frontrange, and Pathfinder uplifts. Ransome's Wyoming lineament approximates the parallel east-northeast trend of the axis of the Sweetwater trough of Mallory (1972, fig. 4, p. 115), which seems to have been an area of subsidence during much of the Paleozoic (D.L. Macke, oral commun., 1989).

Pennsylvanian deposition was terminated in the Western Interior by a Late Pennsylvanian (Virgilian) to Early Permian (early Wolfcampian) tectonic event. A Missourian-Virgilian unconformity in the southern Rocky Mountain and Cordilleran region suggests that this may have been a pre-Virgilian event; but Virgilian strata, which may have resulted from this diastrophism, are known only from a few places in the Wyoming region. Lower Permian strata lie disconformably above erosionally bevelled Pennsylvanian strata as young as Virgilian at places in the Laramie Mountains and the Colorado Front Range; but they lie unconformably upon Precambrian rocks at places in the Medicine Bow Mountains and provide evidence of rejuvenation of the Ancestral Frontrange uplift. The amplitude of the uplifts of this third stage of the Ancestral Rocky Mountain epeirogeny seems to have been minor. This diastrophism is primarily expressed in Montana by the broad Milk River uplift and in Wyoming by the development of the north-south-trending Wyoming arch that connected the elevated terrains in Colorado and Montana.

Sand eroded in Early Permian time from the Pennsylvanian beds exposed on the Milk River uplift and on the Wyoming arch was deposited on the east and southeast flanks of these uplifts in eolianite beds of the upper member of the Minnelusa Formation, of equivalent age rocks in the upper members of the Hartville and the Casper Formations, and in the Ingleside Formation. Coeval sand was deposited in tongues of the Shedhorn Sandstone and in the lower member of the Grandeur Member of the Park City Formation ("Nowood member" of McCue, 1953) in the Phosphoria sea on the west side of these uplifts. Arkose was deposited very locally adjacent to the Ancestral Frontrange uplift in Colorado and south-central Wyoming and its limited dispersal provides an indication of the low relief of this late stage of the history of the Ancestral Rockies. 


\section{References}

Kluth, Charles F., 1986, Plate tectonics of the ancestral Rocky Mountains, in Paleotectonics and sedimentation, Rocky Mountain region, USA, J. A. Peterson, ed.: American Association of Petroleum Geologists Memoir, 41, p.353-369.

Lageson, D.R., Maughan, E.K., and Sando, W.J., 1979, The Mississippian and Pennsylvanian (Carboniferous) Systems in the United StatesWyoming: U.S. Geological Survey Professional Paper 1110-U, 38 p.

Mallory, w.w., 1972, Regional synthesis of the Pennsylvanian System, in Geologic Atlas of the Rocky Mountain region, W.W. Mallory, editor: Rocky Mountain Association of Geologists, Denver, p. 111-127.

Maughan, E.K., 1975, Montana, North Dakota, northeastern Wyoming and northern South Dakota, : $O$, in Paleotectonic investigations of the Pennsylvanian System in the United States; Part I, Introduction and regional analyses of the Pennsylvanian System, E.D. McKee, E.J. Crosby, and others, compilers: U.S. Geological Survey Professional Paper, 853, p. 279-293.

Maughan, E. K., 1983, Tectonic setting of the Rocky Mountain region during the late Paleozoic and early Mesozoic, in Symposium on Genesis of Rocky Mountain ore deposits--Changes with time and tectonics: Denver Region Exploration Geologists Society, Proceedings Volume, p. 31-50.

Maughan, E.K., and Perry, W.J., Jr., 1986, Lineaments and their tectonic implications in the Rocky Mountains and adjacent plains region, in Paleotectonics and sedimentation, Rocky Mountain region, USA, J. A. Peterson, ed.: American Association of Petroleum Geologists Memoir, 41, p.41-53.

McCue, J.J., 1953, Facies changes within the Phosphoria Formation in the southeast portion of the Big Horn Basin, Wyoming: Wyoming University, unpublished M.A. thesis.

Ransome, F.L., 1915, The Tertiary orogeny of the North American cordillera and its problems, in Problems of American geology, W.N. Rice and others: Yale University Press, New Haven, Conn., p. 287-376.

Saperstone, H.I., and Ethridge, F.G., 1984, Origin and paleotectonic setting of the Pennsylvanian Quadrant Sandstone, southwestern Montana. in The Permian and Pennsylvanian Geology of Wyoming, J. Goolsby and D. Morton, editors: Wyoming Geological Association 35th Annual Field Conference Guidebook, p. 309-331. 


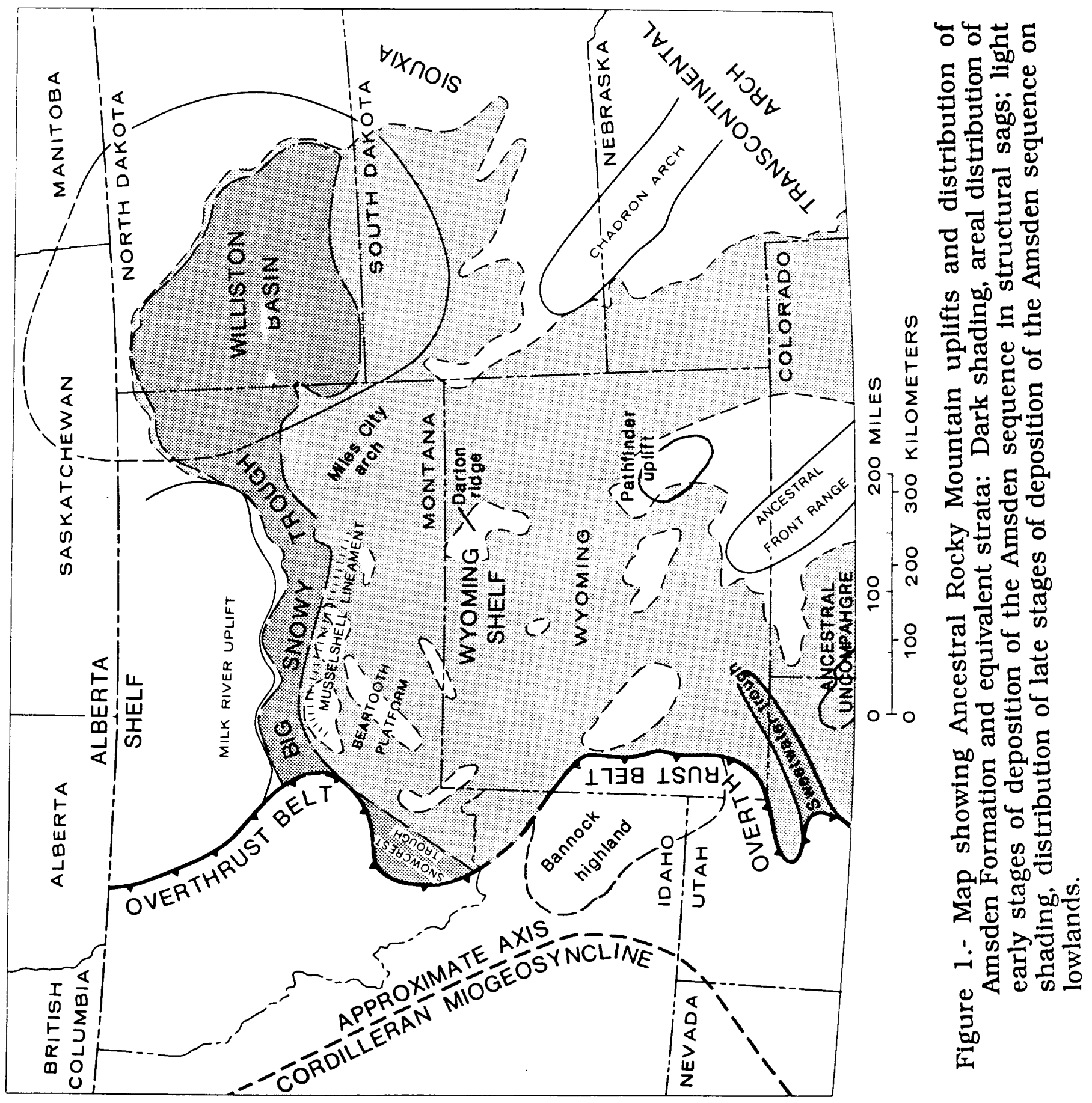




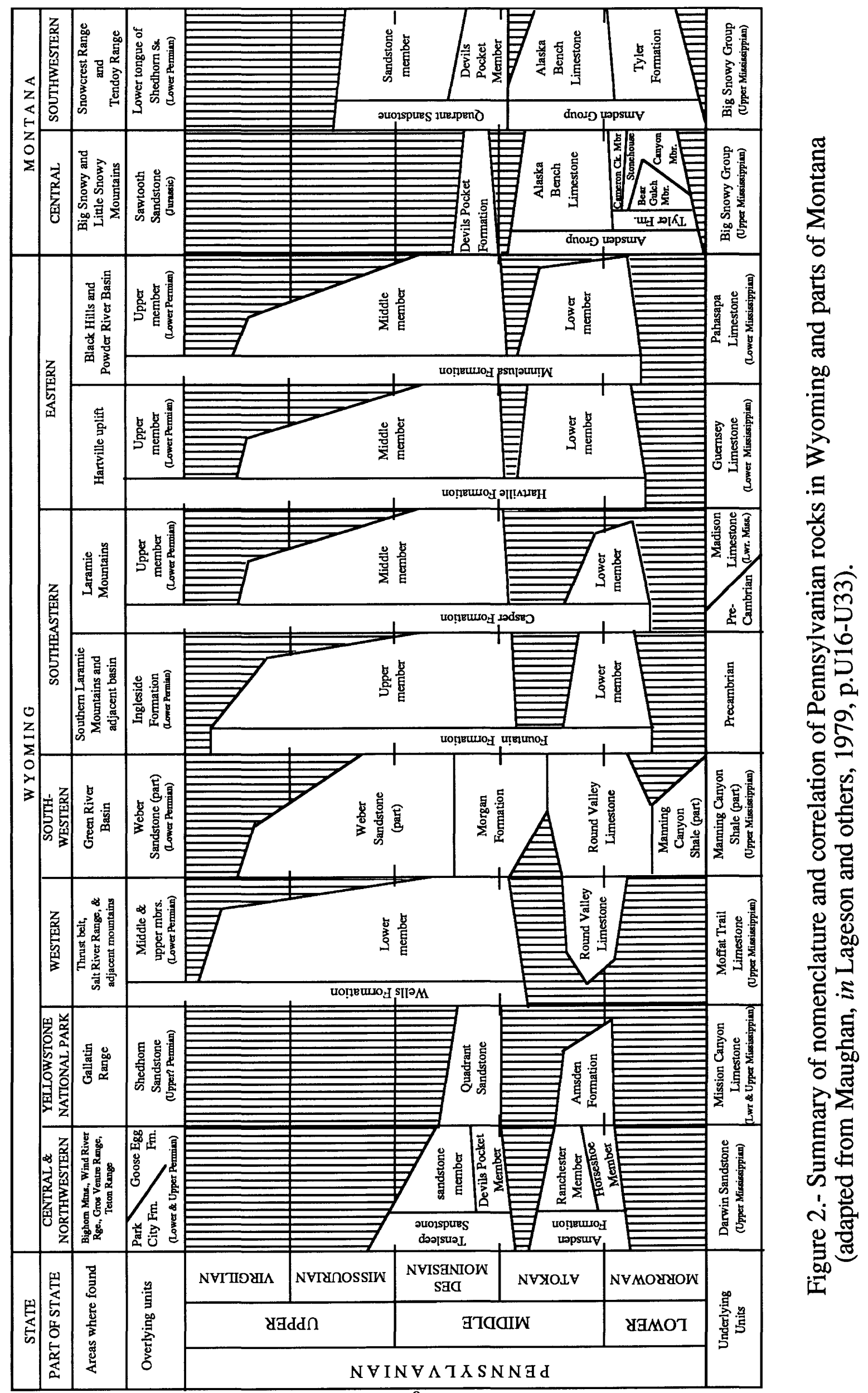

